\title{
Karyotype of the invasive species Pterois volitans (Scorpaeniformes: Scorpaenidae) from Margarita Island, Venezuela
}

\author{
Mauro Nirchio ${ }^{1 *}$, Nicolás Ehemann ${ }^{1}$, Raquel Siccha-Ramirez ${ }^{2}$, Ernesto Ron ${ }^{1}$, Julio Eduardo \\ Pérez $^{3}$, Anna Rita Rossi ${ }^{4} \&$ Claudio Oliveira ${ }^{2}$ \\ 1. Escuela de Ciencias Aplicadas del Mar, Universidad de Oriente, Isla de Margarita, Venezuela; \\ mauro.nirchio@gmail.com,ne1987@gmail.com, ernesto.ron@gmail.com \\ 2. Departamento de Morfologia, Instituto de Biociências Universidade Estadual Paulista, 18618-970 Botucatu, São \\ Paulo, Brazil; raquelisabell@hotmail.com, claudio@ibb.unesp.br \\ 3. Instituto Oceanográfico de Venezuela, Universidad de Oriente, Cumaná Venezuela; jeperezr@yahoo.com \\ 4. Department of Biology and Biotechnology, University of Rome "La Sapienza", via Borelli 50, 00161 Rome, Italy; \\ annarita.rossi@uniroma1.it \\ * Correspondence
}

$$
\text { Received 17-I-2014. Corrected 27-VI-2014. Accepted 29-VII-2014. }
$$

\begin{abstract}
The genus Pterois includes nine valid species, native to the Red Sea and Indian Ocean throughout the Western Pacific. P. volitans and P. miles are native to the Indo-Pacific, and were introduced into Florida waters as a result of aquarium releases, and have been recently recognized as invaders of the Western Atlantic and Caribbean Sea (Costa Rica to Venezuela). Thus far, cytogenetic studies of the genus Pterois only cover basic aspects of three species, including P. volitans from Indo-Pacific Ocean. Considering the lack of more detailed information about cytogenetic characteristics of this invasive species, the objective of the present study was to investigate the basic and molecular cytogenetic characteristics of P. volitans in Venezuela, and compare the results with those from the original distribution area. For this, the karyotypic characteristics of four lionfish caught in Margarita Island, Venezuela, were investigated by examining metaphase chromosomes by Giemsa staining, C-banding, Ag-NOR, and two-colour-Fluorescent in situ hybridization (FISH) for mapping of $18 \mathrm{~S}$ and $5 \mathrm{~S}$ ribosomal genes. Comparing the sequences of the $16 \mathrm{~S}$ gene of the specimens analyzed, with sequences already included in the Genbank, we corroborated that our specimens identified as $P$. volitans are in fact this species, and hence exclude the possibility of a misidentification of $P$. miles. The diploid number was $2 \mathrm{n}=48$ $(2 \mathrm{~m}+10 \mathrm{sm}+36 \mathrm{a})$ with $\mathrm{FN}=60$. Chromosomes uniformly decreased in size, making it difficult to clearly identify the homologues except for the only metacentric pair, and the pairs number two, the largest of the submetacentric series. C-banding revealed only three pairs of chromosomes negative for C-band, whereas all remaining chromosomes presented telomeric and some interstitial C-positive blocks. Only two chromosomes were C-banding positive at the pericentromeric regions. Sequential staining revealed Ag-NOR on the tips of the short arms of chromosome pair number two and the FISH assay revealed that 18S rDNA and 5S rDNA genes are co-located on this chromosome pair. The co-localization of 5S rDNA and 45S rDNA is discussed. Both constitutive heterochromatin and NOR location detected in samples examined in this study, differ from those reported for $P$. volitans in previous analysis of specimens collected in Indian Ocean (Java), suggesting the occurrence of chromosome microrearrangements involving heterochromatin during the spread of P. volitans. Rev. Biol. Trop. 62 (4): 1365-1373. Epub 2014 December 01.
\end{abstract}

Key words: karyotype, $18 \mathrm{~S}$ and $5 \mathrm{~S}$ ribosomal genes, $16 \mathrm{~S}$ rRNA mitochondrial gene, molecular identification, invasive species. 
The genus Pterois (Linnaeus, 1758) (Scorpaeniformes: Scorpaenidae) contains nine valid species, native to the Red Sea and Indian Ocean throughout the Western Pacific (Schultz 1986). Two similar species, the red lionfish P. volitans (Linnaeus, 1758), and the devil firefish P. miles, have been considered in the past as a synonymy (Beaufort \& DeBriggs, 1962; Dor, 1984), but Shultz (1986) demonstrated that they can be distinguished by dorsal- and analfin rays counts ( $P$. volitans usually has 11 dorsal and seven anal-fin rays while $P$. miles, has generally 10 dorsal and six anal-fin rays). More recently, sequence analyses of mitochondrial genes resolved specimens of $P$. miles and $P$. volitans in distinct monophyletic clades providing molecular evidence that they are different species (Freshwater et al., 2009).

$P$. volitans and $P$. miles are native to the Indo-Pacific and were introduced into Florida waters as a result of aquarium releases (Courtenay, 1995; Whitfield et al., 2002; Semmens et al., 2004), and are recognized as recent invaders of the Western Atlantic and Caribbean Sea (Costa Rica to Venezuela), with hundreds of sightings documented after the first lionfish was reported in May 2009 off the coast of South America (González et al., 2009; Lasso-Alcalá \& Posada, 2010). Although their populations are expanding rapidly throughout North-West Atlantic and the Caribbean Sea (Whitfield et al., 2007), 93\% of the Atlantic samples of lionfish consist of $P$. volitans and only 7\% correspond to P. miles (Hamner et al., 2007).

In response to their proliferation throughout the Caribbean, the International Coral Reef Initiative (ICRI) set up an ad-hoc committee, held a workshop in order to develop a region-wide strategy for lionfish control and management that requires achieving all possible information specifically with their impact, reproduction and genetics (http://www.icriforum.org/ icri-meetings/icri-regional-lionfish-workshop).

As long as lionfish invasion continues, genetic research will become a powerful tool for assessing pathways of dispersion, populations divergence, expression of invasion-driving phenotypes, and possibly detection of new introduction events. Thus, the development of high-resolution lionfish genetic markers will allow a more throughout investigation of this invasion, providing a better understanding of both invasion genetics and marine phylogeography (Morris \& Green, 2012).

This paper presents a molecular and cytogenetic characterization of lionfish collected at Margarita Island, Venezuela, reporting the chromosome number and formula, constitutive heterochromatin distribution by C-banding, and the locations of ribosomal genes by $\mathrm{Ag}$ staining and fluorescent in situ hybridization (FISH). It will also include the description of co-localization of the major and minor ribosomal genes, and information about sequences of the mitochondrial gene $16 \mathrm{~S}$, with the aim to contribute to achieve genetic information on this invasive species.

\section{MATERIALS AND METHODS}

Study site: Four specimens of lionfish collected at Margarita Island $\left(10^{\circ} 57^{\prime} 7^{\prime \prime} \mathrm{N}\right.$ $64^{\circ} 9^{\prime} 50^{\prime}$ 'W), Venezuela, were analyzed. All the specimens were identified as Pterois volitans according to Shultz (1986), and vouchers were deposited in the fish collection of the Laboratório de Biologia e Genética de Peixes, UNESP, Botucatu, São Paulo, Brazil (LBP13291), and Laboratorio de Citogenética de Peces of Escuela de Ciencias Aplicadas Del Mar, Universidad de Oriente, Nueva Esparta, Venezuela (ECAM880, ECAM- 901, ECAM-949).

Molecular analysis: In order to molecularly corroborate the taxonomic identification of the specimens of lionfish here studied, a fragment $(542 \mathrm{bp})$ of $16 \mathrm{~S}$ rRNA mitochondrial gene was amplified and sequenced for a subset of two specimens and compared with the same gene fragment corresponding to $P$. volitans, $P$. mombasae, $P$. milles, $P$. radiata and $P$. antennata retrieved from the Genbank. For this molecular analysis, total DNA was obtained from small fragments of muscular tissue, applying the methodology of extraction in saline solution described by Aljanabi et al. 
(1997). A partial sequence of about 542 bp of the gene 16S rRNA was amplified using the primers 16S-F 5' ACG CCT GTT TAT CAA AAA CAT 3' and 16S-R 5' CCG GTC TGA ACT CAG ATC ACG T 3' (Kocher et al. 1989). Amplified DNA segments were visualized in $1 \%$ agarose gel, using Blue Green Loading Dye I (LGC biotechnology). PCR products were purified through ExoSap-IT ${ }^{\circledR}$ (USB Corporation) and sequenced using BigDye Terminator v 3.1 (Applied Biosystems) according to the manufacturer's instructions in a ABI3130 (Perking-Elmer) sequencer.

Chromosome analysis: Chromosome preparations were obtained from kidney cells as described in Nirchio \& Oliveira (2006). Kidney cells suspensions were obtained from fishes injected intramuscularly with yeast glucose solution for mitosis stimulation 24 hours before injecting colchicine (Lee \& Elder, 1980). Silver-stained nucleolus organizer regions (Ag-NORs) were obtained as described by Howell \& Black (1980). C-bands were obtained following the method of Sumner (1972).

The $5 \mathrm{~S}$ and $18 \mathrm{~S}$ rDNA sites were identified by FISH according to the method proposed by Pinkel et al. (1986). Probes used to localize the 45S rDNA sites were obtained from total DNA of Characidium zebra using the primers $18 \mathrm{~S} F$ (5' CCG TGA TGG CTC CTT TTG AT 3') and 18S R (5' CCG AGG ACC TCA CTA AAC CA 3 '). These probes were labeled with Digoxigenin-11-dUTP (Roche Applied Science) by PCR and the hybridization signal detection was performed using anti-digoxigenin-rhodamine (Roche Applied Science). 5S rDNA was mapped using a probe obtained by PCR from the total DNA of Synbranchus marmoratus using the primers 5S F (5' GCC CGA TAC CGT CCG ATC TCT 3') and 5S R (5' CAG GCT GCC ATG GGT GTA ACG 3'). These probes were labeled with Biotin-16-dUTP (Roche Applied Science) by PCR and the hybridization signal detection was performed using conjugated Avidin-Fluorescein.

The slides were incubated with RNAse $(40 \mu \mathrm{g} / \mathrm{mL})$ at $37^{\circ} \mathrm{C}$ for one hour. After that,
DNA denaturation in formamide $70 \% / 2 x S S C$ at $70^{\circ} \mathrm{C}$ for two minutes was performed and the chromosome preparations were dehydrated in an ethanol series $(70,85$, and $100 \%)$. After drying, the hybridization mix (100ng probes, $10 \mathrm{mg} / \mathrm{mL}$ dextran sulfate, $2 \mathrm{xSSC}$, and $50 \%$ formamide in a $30 \mu \mathrm{L}$ final volume) was pipetted onto the samples, which were then incubated overnight at $37^{\circ} \mathrm{C}$ in a humid chamber. After hybridization, the slides were washed $2 \mathrm{X}$ for 10 minutes in $15 \%$ formamide solution/ $0.2 x \mathrm{SSC}$ $\mathrm{pH} 7.0$ at $42^{\circ} \mathrm{C}$, followed by $3 \mathrm{X}$ washes in $0.1 \mathrm{xSSC}$ at $60^{\circ} \mathrm{C}$ for five minutes each; the slides were then incubated in 5\% NFDM/4xSSC buffer for 15 minutes and washed with Tween $0.5 \% / 4 \mathrm{xSSC}$ for five minutes at room temperature with shaking. Probe detection was done with $0.07 \%$ avidin-FITC (Sigma) conjugated with NFDM/4xSSC buffer for 30 minutes, followed by signal amplification using $2.5 \%$ antividin-biotin conjugated with NFDM/4xSSC buffer for 30 minutes. Treatments with avidinFITC and antividin-biotin were accomplished at $37^{\circ} \mathrm{C}$ in a humid chamber. After each step of signal detection, the slides were washed $3 \mathrm{X}$ with $0.5 \% / 4 \mathrm{xSSC}$ Tween for five minutes at room temperature. Chromosomes were counterstained with antifade/DAPI.

The mitotic figures were photographed using a Motic B410 microscope equipped with a Motic Moticam 5000C digital camera. Chromosomes were classified according to the arm ratio criteria (Levan et al., 1964). FISH metaphases were photographed with an Olympus BX61 photomicroscope equipped with a DP70 digital camera. Images were digitally processed with ADOBE $^{\circledR}$ PHOTOSHOP CS6 Extended ${ }^{\circledR}$.

\section{RESULTS}

The alignment of two sequences (542pb) of the 16S rRNA mitochondrial gene corresponding to samples identified as Pterois volitans and 12 sequences retrieved from Genbank, corresponding to the species $P$. volitans, $P$. mombasae, $P$. miles, $P$. radiata and $P$. antennata), allowed detecting the existence of 519 
conserved sites, 23 variable sites, 20 parsimony informative sites and three sites with unique mutations. Figure 1 shows the phylogenetic trees constructed using the methods of maximum likelihood and maximum parsimony, both presenting identical topology and demonstrating the existence of two monophyletic lineages supported by high bootstrap values: one consisting of the species $P$. mombasae, $P$. antennata and $P$. radiata and another consisting of $P$. volitans and $P$. miles. In all specimens of $P$. volitans here examined the diploid number was $2 \mathrm{n}=48(2 \mathrm{~m}+10 \mathrm{sm}+36 \mathrm{a})$ with $\mathrm{FN}=60$ (Table 1, Fig. 2). Chromosomes uniformly decreased in size, making it difficult to clearly identify the homologues except for the only metacentric pair number one, and the pair number two, the largest of the submetacentric series. Figure 3 (A, B) shows a sequentially stained plate that allowed the identification of the NOR-bearing chromosomes.

Most of the chromosomes showed telomeric and/or interstitial C-positive blocks. In addition two chromosomes showed C-positive bands in the pericentromeric regions (Fig. 4).

Chromosomal mapping of $5 \mathrm{~S}$ and $45 \mathrm{~S}$ rDNA performed by multi-colour FISH using biotin-labeled and digoxigenin-labeled probes is shown in figure 5. In simultaneous hybridization Biotin-16-dUTP-labelled 5S rDNA probe was detected as a yellow signal (Fig. 5B) whereas Digoxigenin-11-dUTP-labeled $18 \mathrm{~S}$ rDNA was detected as a red signal (Fig. $5 \mathrm{C}$ ) and revealed the co-localization of $5 \mathrm{~S}$ and $18 \mathrm{~S}$ rRNA genes in the chromosome pair number 2 .

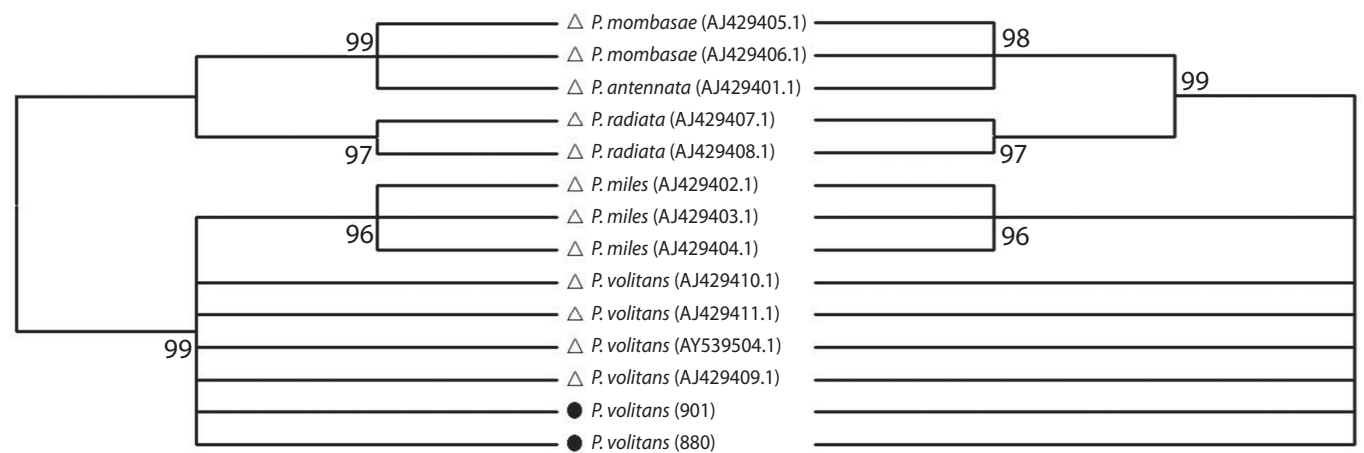

Fig. 1. Phylogenetic trees constructed using maximum likelihood (left) and maximum parsimony (right) methods. Black circles correspond to the specimens used in the present study.

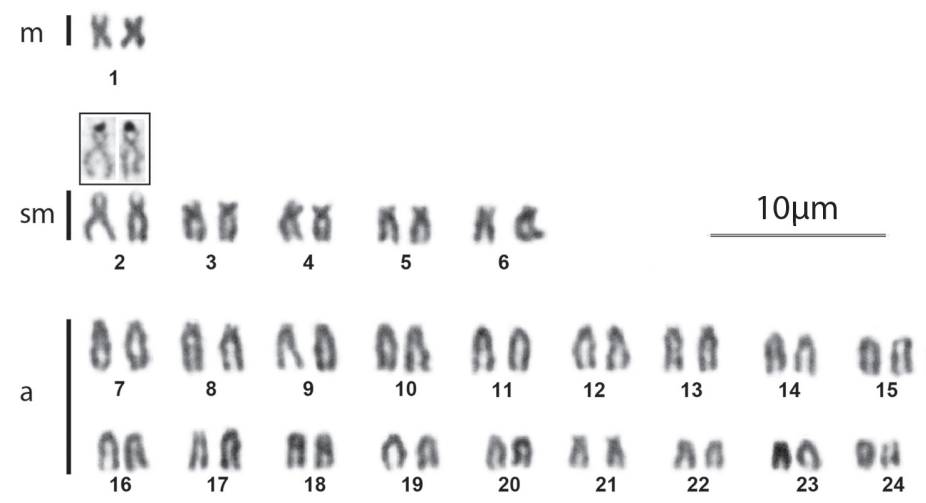

Fig. 2. Giemsa-stained karyotype of Pterois volitans. 
TABLE 1

Chromosome data for the Pterois lunulata, $P$. radiate and $P$. volitans

\begin{tabular}{lccccccccc}
\multicolumn{1}{r}{$\quad$ Species } & 2n & Karyotype & NF1/NF2 & Ag-NORs & 18S-rDNA & 5S-rDNA & C-bands & Locality & Ref. \\
Pterois lunulata & 48 & $2 \mathrm{~m}+12 \mathrm{st}+34 \mathrm{a}$ & $52 / 58$ & 2 & 2 & & + & Indian Ocean & 1 \\
P. lunulata & 48 & $2 \mathrm{~m}+10 \mathrm{sm}+18 \mathrm{st}+18 \mathrm{a}$ & $60 / 78$ & - & - & - & - & Japan & 2 \\
P. radiata & 48 & $4 \mathrm{~m}+8 \mathrm{st}+36 \mathrm{a}$ & $52 / 60$ & 2 & 2 & - & + & Indian Ocean & 1 \\
P. volitans & 48 & $2 \mathrm{~m}+10 \mathrm{st}+36 \mathrm{a}$ & $50 / 60$ & 2 & 2 & - & + & + Indian Ocean & 1 \\
P. volitans & 48 & $2 \mathrm{~m}+10 \mathrm{sm}+36 \mathrm{a}$ & 60 & 2 & 2 & 2 & + Venezuela & 3 \\
\hline
\end{tabular}

NF1 shows fundamental arm number, when only $\mathrm{m}$ and sm are counted as two-armed. NF2 shows fundamental arm number, when m, sm, and st are counted as bi-armed. [References: 1- Caputo et al. (2003); 2- Nishikawa et al. (1977); 3- present paper].
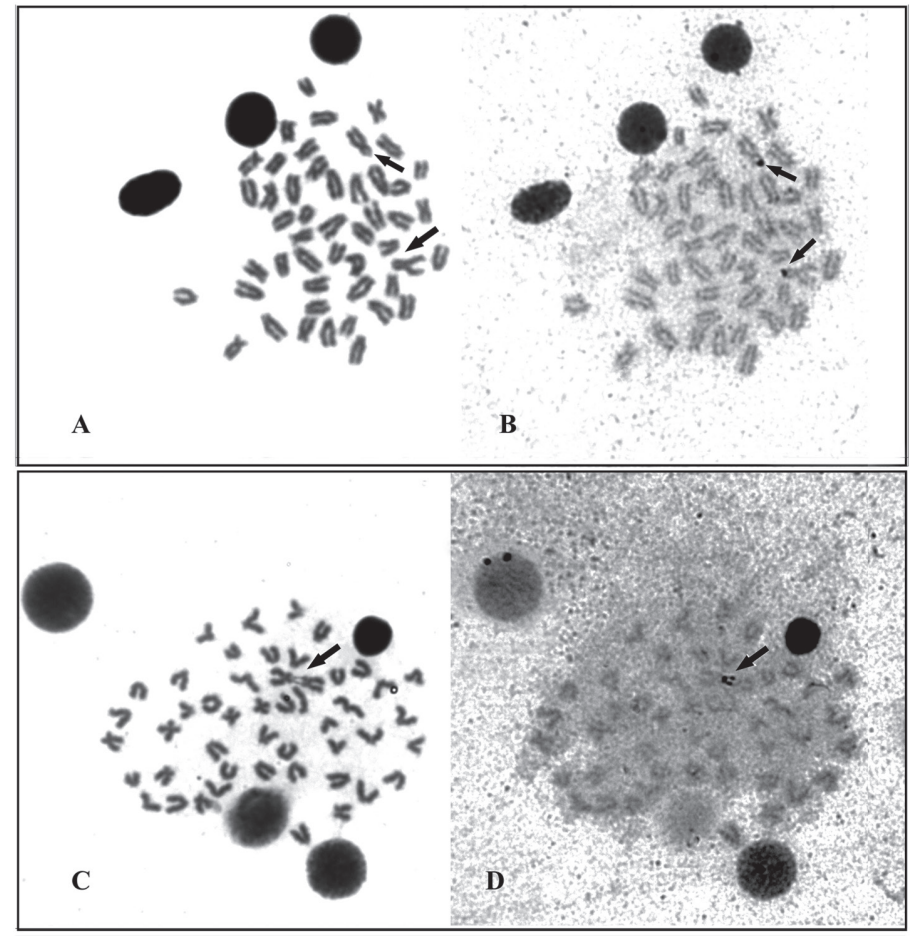

Fig. 3. Sequential Giemsa (A, C) and $\mathrm{AgNO}_{3}$-stained (B,D) plate of Pterois volitans. Plates C, D show chromosome association. Arrows indicate the NOR-bearing chromosome.

\section{DISCUSSION}

The overall mean genetic distance between the sequences here analyzed was $\mathrm{d}=0.0166$, which reveals that nucleotide differences are small, even amongst taxonomic units recognized as different species $(\mathrm{d}=0.0122$ between $P$. volitans and $P$. miles; $\mathrm{d}=0.0121$ between $P$. radiata and $P$. mombasae; $\mathrm{d}=0.0131$ between $P$. radiata and $P$. antennata; $\mathrm{d}=0.0028$ between P. mombasae and P. antennata). However, the comparisons of the $16 \mathrm{~S}$ gene sequences of the specimens analyzed in the present study with sequences already included in GenBank, corroborate that the specimens studied here belong to a clade that incudes exclusively other 


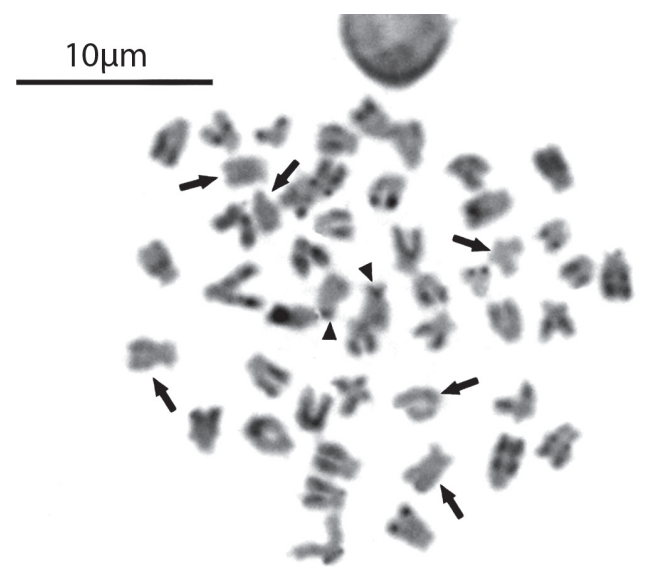

Fig. 4. C-banded metaphase of Pterois volitans. Arrows indicate negative chromosomes for C-banding. Arrowheads indicate chromosomes with pericentromeric heterochromatin. from subjective attribution of small chromosomes to sm or st categories, rather than representing real polymorphisms (Arai, 2011). Thus it is likely that differences in the karyotype of $P$. volitans between this study and published data by Caputo et al. (2003) are due to differences in classification of few chromosome pairs.

However differences between Indian Ocean and Venezuelan $P$. volitans samples were detected both in NORs location and C-bands. Indeed Caputo et al. (2003) reported the presence of terminal-centromeric located Ag-NORs on the short arms of a pair of subtelocentrics elements, while samples examined in this study have the Ag-NORs located on the short arm of the largest submetacentric chromosome pairs classified as number two.

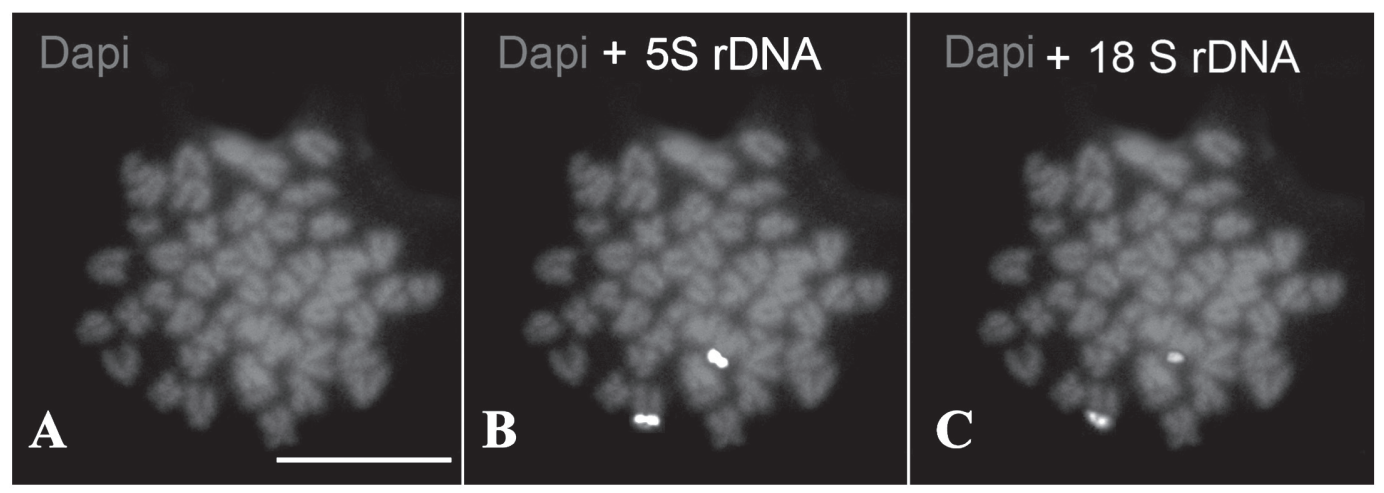

Fig. 5. Fluorescence in situ hybridization of 5S rRNA and 18S rRNA genes in Pterois volitans chromosomes. (A) DAPI, (B) hybridization signal of 5S rDNA, (C) hybridization signal of 18S rDNA. Note the co-localization of 18S and 5S rDNA. Chromosomes are counterstained with DAPI and the group of images (A, B and $\mathbf{C}$ ) is the same metaphases submitted to two-colour FISH. Bar=10 $\mu \mathrm{m}$.

sequences of $P$. volitans, and hence excluding the possibility of a misidentification of $P$. miles.

Thus far, cytogenetic studies of the genus Pterois only cover three species indicating for $P$. volitans identical diploid number of chromosomes with differing number of arms. Caputo et al. (2003) reported for this species a karyotype, $2 \mathrm{n}=48,2 \mathrm{~m}+10 \mathrm{st}+36 \mathrm{a}$, that differs from the karyotype described here as $2 \mathrm{n}=48$, $2 \mathrm{~m}+10 \mathrm{sm}+36 \mathrm{a}$. In some cases, differences in karyotype formula reported by different authors may derive from technical artifacts or
Some metaphase plates showed association by a heteropycnotic tips on the short arm of these chromosome explaining why some interphase cells shows two nucleoli whereas others display only one.

Constitutive heterochromatin was identified only in four homologues in Javanese $P$. volitans, located at centromeric and interstitial positions (Caputo et al., 2003), whereas in the samples studied here almost all chromosomes exhibited C-positive blocks. Indeed only three pairs of chromosomes were negative for 
C-banding with all remaining ones presenting telomeric and some interstitial C-positive blocks and, in some cases, interstitials. Only two chromosomes showed pericentromeric heterochromatic regions. Since the presence of interstitial C-heterochromatin would reveal the occurrence of chromosomal rearrangements by pericentric inversions (Zenzes \& Voiculescu, 1975), chromosome microrearrangements involving heterochromatin seem to have occurred during the spread of $P$. volitans which is consistent with the significant molecular differentiation of lionfish reported by Betancur et al. (2011) between the Northern (US east coast, the Bahamas and Bermuda) and the Caribbean populations of $P$. volitans of the Western Atlantic.

Extensive mapping of the $45 \mathrm{~S}$ and $5 \mathrm{~S}$ rDNA in fish has revealed a non-association of the two classes of ribosomal genes in fish genomes, with most species having these sequences on different chromosomes (Cioffi \& Bertollo, 2012). Co-localization of $5 \mathrm{~S}$ rDNA and $45 \mathrm{~S}$ rDNA could facilitate translocations between the $5 \mathrm{~S}$ and $45 \mathrm{~S}$ cluster, causing disruptive interference in the structure and function of such genes (Nirchio \& Oliveira, 2006) and, therefore, possibly explain why the majority of vertebrates have the $5 \mathrm{~S}$ and $45 \mathrm{~S}$ rDNA clusters on different chromosomes (Martinez et al., 1996; Fujiwara et al. 1998; Ferro et al., 2001) this arrangement being evolutionarily advantageous. The presence of clusters of these sequences either very close to or far apart from each other on the same chromosome has already been reported in teleosts including Salmo salar (Pendás et al., 1994), Oncorhynchus mykiss (Morán et al., 1996), Acheilognathus tabira subsp. 1, Cyprinus carpio (Inafuku et al., 2000), Rhomboplites aurorubens (Nirchio et al., 2009) and Mugil incilis (Hett et al., 2011). Although the terminal localization of single major ribosomal genes on the short arm of a pair of chromosomes seems to be a shared feature among the species of lionfish cytogenetically studied until now (Caputo et al., 2003; this paper), reports on co-localization of $18 \mathrm{~S}$ and $5 \mathrm{~S}$ ribosomal genes in $P$. volitans, as revealed by the multi-colour
FISH are restricted to this study. Thus, further investigations of $5 \mathrm{~S}$ and $45 \mathrm{~S}$ ribosomal genes in other Pterois species are required to provide a more throughout analysis of the evolution of these repetitive sequences in the genome of this fish genus.

\section{ACKNOWLEDGMENTS}

This work was supported by Consejo de Investigación, Universidad de Oriente, Venezuela, and by Fundação de Amparo à Pesquisa do Estado de São Paulo (FAPESP), Brazil and Conselho Nacional de Desenvolvimento Científico e Tecnológico (CNPq), Brazil, to CO.

\section{RESUMEN}

Cariotipo de la especie invasora Pterois volitans (Scorpaeniformes: Scorpaenidae) de Isla Margarita Island, Venezuela. El género Pterois contiene nueve especies válidas, nativas del Mar Rojo y el Océano Índico en el Pacífico occidental. $P$. volitans y $P$. miles son nativas del Indo-Pacífico, y fueron introducidas en las aguas de Florida como resultado de la liberación de peces confinados en acuario y han sido reconocidas recientemente como invasoras en el Atlántico Occidental y Mar Caribe (Costa Rica hasta Venezuela). Los estudios citogenéticos realizados hasta ahora en el género Pterois cubren solamente aspectos básicos de tres especies que incluyen a $P$. volitans del océano Indo-Pacífico. Debido a la ausencia de información detallada sobre las características cromosómicas de esta especie invasora, el objetivo del presente estudio fue investigar las características citogenéticas en ejemplares de Venezuela mediante técnicas convencionales y moleculares y comparar los resultados con los reportados para el área de distribución original. Para ello, se investigaron las características cariotípicas mediante tinción con Giemsa, bandeo-C, impregnación con Nitrato de Plata (Ag-NOR) e hibridación fluorescente in situ (FISH) dual para localizar los genes ribosomales $18 \mathrm{~S}$ rDNA y $5 \mathrm{~S}$ rDNA en cuatro ejemplares de pez león capturados en la Isla Margarita, Venezuela. La comparación de secuencias del gen $16 \mathrm{~S}$ de los especímenes analizados con secuencias ya incluidas en el Genbank permitieron corroborar la identificación de $P$. volitans excluyendo así la posibilidad de una identificación errónea de $P$. miles. El número diploide fue $2 \mathrm{n}=48(2 \mathrm{~m}+10 \mathrm{sm}+36 \mathrm{a})$ con un $\mathrm{FN}=60$. Los cromosomas presentaron tamaños que disminuyen de manera uniforme dificultando la identificación de homólogos, excepto el único par metacéntrico y el par cromosómico número 2 . El bandeo-C reveló tres pares de cromosomas bandas-C negativos, mientras que los restantes presentaron bloques 
bandas-C positivos en posición telomérica y, en algunos casos, intersticial. Sólo dos cromosomas mostraron bandas$\mathrm{C}$ pericentroméricas. La tinción secuencial reveló las AgNOR localizadas en los extremos de los brazos cortos del par número dos y el ensayo FISH demostró que los genes $18 \mathrm{~S}$ rDNA y $5 \mathrm{~S}$ rDNA se localizan en ese mismo par. Se discute la co-localización de los genes 5S rDNA y $18 \mathrm{~S}$ rDNA. La distribución de la heterocromatina constitutiva y localización de las NORs en los peces examinados difirió de la reportada para ejemplares de $P$. volitans del Océano Índico (Java), sugiriendo que durante la propagación de $P$. volitans han ocurrido reorganizaciones cromosómicas que involucran la heterocromatina.

Palabras clave: cariotipo, genes ribosomales $18 \mathrm{~S}$ and 5S, genes mitocondriales16S rARN, identificación molecular, especies invasoras.

\section{REFERENCES}

Aljanabi, S. M. \& Martinez, I. (1997). Universal and rapid salt extraction of high quality genomic DNA for PCR based technique. Nucleic Acids Research, 25, 4692-4693.

Arai, R. (2011.) Fish Karyotypes. A Check List. Tokio: Springer.

Beaufort, L. F. \& De Briggs, J. C. 1962. The fishes of the Indo-Australian archipelago. I. Leiden: Brill.

Betancur, R. R., Hines, A., Acero, A. P., Ortí, G., Wilbur, A. E., \& Freshwater, D.W. (2011). Reconstructing the lionfish invasion: insights into Greater Caribbean biogeography. Journal of Biogeography, 38, 1281-1293.

Caputo, V., Nisi, C. P., Caniglia, M., \& Giovannotti, M. (2003). Chromosomal studies of five tropical scorpaeniform fishes (Teleostei, Scorpaenidae). Italian Journal of Zoology, 70, 201-204.

Cioffi, M. B. \& Bertollo, L. A. C. (2012). Chromosomal Distribution and Evolution of Repetitive DNAs in Fish. In M. A. Garrido-Ramos (Ed.) Repetitive DNA. (Vol. 7, pp. 197-221). Genome Dyn. Basel: Karger (DOI: $10.1159 / 000337950$ ).

Courtenay, W. R. (1995) Marine fish introductions in southeastern Florida. American Fisheries Society Introduced Fish Section Newsletter, 2-3.

Dor, M. (1984). CLOFRES, Checklist of the fishes of the Red Sea. Jerusalem: Israel Academy of Science and Humanities.

Ferro, D. A., Neo, D. M., Moreira-Filho, O., \& Bertollo, L. A. C. (2001). Nucleolar organizing regions, $18 \mathrm{~S}$ and 5S rDNA in Astyanax scabripinnis (Pisces, Characidae): populations distribution and functional diversity. Genetica, 110, 55-62.

Freshwater, D. W., Hamner, R. M., Parham, S., \& Wilbur, A. E. (2009). Molecular evidence that the lionfishes
Pterois miles and Pterois volitans are distinct species. Journal of the North Carolina Academy of Science, 125(2), 39-46.

Fujiwara, A., Abe, S., Yamaha, E., Yamazaki, F., \& Yoshida, M. C. (1998). Chromosomal localization and heterochromatin association of ribosomal RNA genes loci and silver stained nucleolar organizer regions in salmonid fishes. Chromosome Research, 6, 463-471.

González, J., Grijalba-Bendeck, M., Acero, P. A., \& Betancur, R. (2009). The invasive Indo-Pacific lionfish, Pterois volitans/miles complex, in the southern Caribbean Sea. Aquatic Invasions, 4, 507-510.

Hamner, R. M., Freshwater, D. W., \& Whitfield, P. E. (2007). Mitochondrial cytochrome $b$ analysis reveals two invasive species with strong founder effects in the western Atlantic. Journal of Fish Biology, 71 (Sup B), 214-222.

Hett, A. K., Nirchio, M., Oliveira, C., Siccha, Z. R., Rossi, A. R., \& Sola, L. (2011). Karyotype characterization of Mugil incilis Hancock, 1830 (Mugiliformes: Mugilidae), including a description of an unusual co-localization of major and minor ribosomal genes in the family. Neotropical Ichthyology, 9(1), 107-112.

Howell, W. \& Black, D. (1980). Controlled silver staining of nucleolus organizar regions with a protective colloidal developer: a one-step method. Experientia, 36, 1014-1015.

Inafuku, J., Nabeyama, M., Kikuma, Y., Saitoh, J., Kubota, S., \& Kohno, S. (2000). Chromosomal location and nucleotide sequences of $5 \mathrm{~S}$ ribosomal DNA of two cyprinid species (Osteichthyes, Pisces). Chromosome Research, 8, 193-199.

Kocher, T. D., Thomas, W. K., Meyer, A., Edwards, S. V., Pääbo, S., Villablanca, F. X., \& Wilson, A. C. (1989). Dynamics of mitochondrial DNA evolution in animals: Amplification and sequencing with conserved primers. Proceedings of the National Academy of Sciences, 86, 6196-6200.

Lasso-Alcalá, O. M. \& Posada, J. M. (2010). Presence of the invasive red lionfish, Pterois volitans (Linnaeus, 1758), on the coast of Venezuela, southeastern Caribbean Sea. Aquatic Invasions, 5, S53-59.

Lee, M. R. \& Elder, F. F. B. (1980). Yeast stimulation of bone marrow mitosis for cytogenetic investigations. Cytogenetics and Cell Genetics, 26, 36-40.

Levan, A., Fredga, K., \& Sandberg, A. (1964). Nomenclature for centromeric position on chromosomes. Hereditas, 52, 201-220.

Martínez, J. L, Móran, P., Garcia-Vásquez, E., \& Pendás, A. M. (1996). Chromosomal localization of the major and minor 5S rRNA genes in the European eel (Anguilla anguilla). Cytogenetics and Cell Genetics, 73,149-152. 
Moran, P., Martinez, J., Garcia-Vazquez, E., \& Pendas, A. (1996). Sex linkage of $5 \mathrm{~S}$ rDNA in rainbow trout (Oncorhynchus mykiss). Cytogenetics and Cell Genetics, 75, 145-150.

Morris, J. A. Jr. \& Green, S. J. (2012). Lionfish Research: Current Findings and Remaining Questions. In J.A. Morris Jr. (Ed.) Invasive Lionfish: A Guide to Control and Management (pp. 3-14). Gulf and Caribbean Fisheries Institute Special Publication Series Number 1, Marathon, Florida, USA.

Nirchio, M. \& Oliveira, C. (2006). Citogenética de peces. Nueva Esparta, Venezuela: Coordinación de publicaciones del rectorado de la Universidad de Oriente.

Nirchio, M., Oliveira, C., Ferreira, D. C., Rondón, R., Pérez, J. E., Hett, A. K., Rossi, A. R., \& Sola, L. (2009). Cytogenetic characterization of Rhomboplites aurorubens and Ocyurus chrysurus, two monotypic genera of Lutjaninae from Cubagua Island, Venezuela, with a review of the cytogenetics of Lutjanidae (Teleostei: Perciformes). Neotropical Ichthyology, 7, 587-594.

Nishikawa, S., Honda, M., \& Wakatsuki, A. (1977) Comparative studies on the chromosomes in Japanese fishes-II. Chromosomes of eight species in scorpionfishes. Journal of the Shimonoseki University of Fisheries, 25, 187-191. (In Japanese with English abstract).
Pendas, A. M., Moran, P., Freije, J. P., \& Garcia-Vazquez, E. (1994). Chromosome mapping and nucleotide sequence of two tandem repeats of Atlantic salmon 5S rDNA. Cytogenetics and Cell Genetics, 63, 31-36.

Schultz, E. T. (1986). Pterois volitans and Pterois miles: two valid species. Copeia, 3, 686-690.

Semmens, B. X., Buhle, E. R., Salomon, A. K., \& Pattengill-Semmens, C. V. (2004). A hotspot of non-native marine fishes: evidence for the aquarium trade as an invasion pathway. Marine Ecology Progress Series, 266, 239-244.

Sumner, A. (1972). A simple technique for demostrating centromeric heterochromatin. Experimental Cell Research, 75, 304-306.

Whitfield, P. E., Gardner, T., Vives, S. P., Gilligan, M. R., Courtenay, W. R., Ray, G. C., \& Hare, J. A. (2002). Biological invasion of the Indo-Pacific lionfish Pterois volitans along the Atlantic coast of North America. Marine Ecology Progress Series, 235, 289-297.

Whitfield, P. E., Hare, J. A., David, A. W., Harter, S. L., Muñoz, R. C., \& Addison, C. M. (2007). Abundance estimates of the Indo-Pacific lionfish Pterois volitans/ miles complex in the Western North Atlantic. Biological Invasions, 9, 53-64.

Zenzes, M. T. \& Voiculescu, I. (1975). C-banding pattern in Salmo salar, a species of tetraploid origin. Genetica, 45, 531-536. 
